\title{
Bridging the Gap between Practice and Undergraduate Teaching of Operations Management: The Case of Public Liberal Arts Colleges
}

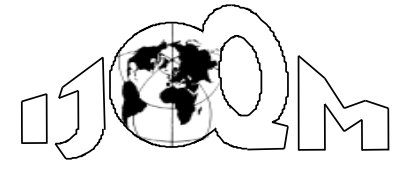

DOI: $10.46970 / 2020.26 .1 .3$

Volume 26, Number 1

March 2020, pp. 49-64

\author{
Romulo B. Magnaye \\ Ramapo College of New Jersey \\ (rmagnaye@ ramapo.edu) \\ Sohail S. Chaudhry \\ Villanova University \\ (sohail.chaudhry@villanova.edu) \\ Brian J. Sauser \\ University of North Texas \\ (brian.sauser@unt.edu) \\ Nikhil Varma \\ Ramapo College of New Jersey \\ (nvarma@ramapo.edu)
}

\begin{abstract}
When teaching Operations Management (OM) in a liberal arts setting, two issues arise - the lack of interest and knowledge retention by the students. This paper suggests that these are due to the lack of integration of OM with other business disciplines when taught and the divergence between what working students experience in practice and how OM is taught. To address these, the paper suggests the use of a familiar strategy model - the value chain - as a platform to show how OM is integrated and interdependent with all other business courses which can raise interest in the subject. To assist with knowledge retention, the paper presents an integrated model of OM where the topics covered in the course are linked to each other as a system. This model can be shown in the beginning of the course and evaluated at the end where participants can contemplate how the model should be expanded/modified to incorporate developments in other fields such as logistics (especially last-mile practices), artificial intelligence or servitization.
\end{abstract}

Keywords: Teaching Operations Management, History of Operations Management, Integrated Model of Operations, Lean Production

\section{Introduction}

As far as Toyota is concerned, “... a person's work may be productive but ... if the work does not contribute to learning and development; it will be classified as waste (Liker et al., 2008, p.38)." Most undergraduate students entering a course in Operations Management (OM) may not have heard of this statement but that is most likely how they feel regarding the subject. It is going to be useless like Statistics and/or Algebra in high school. We can only talk about our own personal experiences as instructors, going all the way back to the late 1980s. However, in talking to other instructors from many institutions during academic and social gatherings, we suspect that this issue is more widespread. Pal and Busing (2008) reported on student apathy towards OM due to a lack of knowledge, limited exposure, and difficulty with the 
quantitative aspects. In addition to the lack of interest or, perhaps, because of it, those who are forced to take the class because it is a required core course do not retain the knowledge and fail to apply the concepts in other courses until they get to the capstone course, usually Strategic Management or Business Policy.

These two issues - lack of interest and knowledge retention - are very serious concerns because of how undergraduate business programs have evolved over time in higher education. There has been great diversity in the content of OM courses. Many business programs have eliminated the OM course from the core curriculum requirements (Raizadeh and Ettkin 1989). This phenomenon is more pronounced when the business program is offered within a liberal arts environment.

Our review of the members of the Council of Public Liberal Arts Colleges (COPLAC 2020) revealed that out of 25 such members who had a business program, only 11 required $\mathrm{OM}$ as a core course for all majors or concentrations. Among the others, only three offered the OM course as an upper level elective ${ }^{1}$. Since all hiring organizations perform operations, the educational institutions without a required OM course are producing job applicants who may not have a complete understanding of all the aspects of organizations. This deficiency needs to be rectified if we are to maintain the long-term credibility of our programs in the liberal arts setting where the main goal is to provide an education with breadth and depth.

This paper attempts to explain how OM became so uninteresting for liberal arts students by looking at how the discipline evolved. We also looked at what teaching innovations have been reported to be successful. Based on these observations, we propose a systemic conceptual model of OM that may increase interest in the subject as well as help students to retain the knowledge. Finally, we make recommendations on where the discipline should be headed given the state of industry where service operations now employ most of our graduates while only a few students end up with a job in the manufacturing sector.

\section{History of Production and Operations Management}

\subsection{Scientific Management}

The earliest documentation of Production and Operations Management (POM) practices can be traced back to Agricola's Re De Metallica published in 1556 (Voss 2007). This body of work was based on a broad thorough empirical survey of the tools and techniques used by practitioners in the field. The compilation of knowledge stopped for a long time as craftsmen and guilds kept their knowledge secret in order to protect their intellectual properties and thus, their jobs. Centuries later, POM began to advance with ideas from Plato (differentiation between occupations), Adam Smith (specialization), and the concepts of automatic control systems in the 1800s. The publications of the American Society of Mechanical Engineers led to the wider acceptance of the scientific management concepts of Frederick Taylor (Thompson 2003) and Henry Ford after he constructed his moving assembly line. These were complemented by Weber's idea on bureaucracy and Fayol's concepts on administration and management control. From these foundations came such concepts

\footnotetext{
${ }^{1}$ Among the top 50 private liberal arts institutions ranked by US News and World Report (2019), only 4 have a business program and 3 of them require OM for all students.
} 
as economic order quantity, queuing theory, assembly lines, statistical quality control, Gantt charts, materials requirements planning, and so on. In general, these were "rough-and-ready theories and techniques derived from lived experiences by real production managers in real factories proven in practical use (Wilson 2018, page 14)." Also, the instructors teaching production management courses were mostly active or retired factory managers without advanced degrees (Wilson 2018).

\subsection{Modern Operations Management}

During the Second World War, industrial engineering and management science techniques were applied to standardize and optimize operations in factories which were building machines and materiel for the war effort. These were quantitative tools designed to find local optimal solutions to achieve, primarily, lower costs and higher productivity.

These quantitative tools continued to be practiced after the war when US factories were operating in a stable business environment due to the lack of foreign competition in the free world. Their widespread inclusion into the POM curriculum became universal after two reports on improving management education were published. These were "The Education of American Businessmen" (Pierson 1959) and "Higher Education for Business" (Gordon and Howell 1959). Both reports were very critical of the way business was being taught, essentially calling for more academic rigor founded on social sciences, humanities, mathematics, and statistics. For POM, incorporating management science and operations research (OR) became a natural response to this criticism. In addition, Industrial engineers began to join business school faculties to teach the OM and related courses (Sprague 2007).

After the two reports were published and business programs responded, the 1960s has been generally regarded as the period when production and operations management became "modern". The discipline was renamed as Operations Management (OM). This was a short-lived period of modernization because the shift turned out to be ineffective. Wilson (2018) observed that with the shift, practical ideas shared by practitioners which dominated in the past became neglected or ignored. These were replaced by "theoretical constructs of an abstract reality" expressed in OR models which were then analyzed to produce optimized results "written in arcane jargon published in low circulation." OR techniques were very elegant powerful tools for solving well-defined specific operations problems. These local optimization results appealed to academics in higher education. Unfortunately, academics, who had very limited or no exposure to actual operations, failed to recognize that industrial practices of OM is much more complex because it cannot be isolated from other parts of the organizations. Even within the OM function, the various components always work together and not in silos isolated from each other. Therefore, optimizing one area typically has adverse effects on the other parts of the organization and vice-versa.

Due to the lack of appreciation or reality, the so-called "modern" view persisted and continued to prevail such that by the 1970s the principles of scientific management were mostly absent from OM curricula and had been replaced by OR and management science techniques (Hayes et al. 2007).

\subsection{Japanese Production Management}


Around the same time, however, US industry, especially manufacturing, began to experience serious foreign competition, especially from Germany and, later, Japan. They produced goods which the American consumer found to be better in quality and also, in the case of Japanese imports, cheaper. Consumer preference for these manufactured imports was so strong such that efforts by the US government and industry to protect domestic operations were ineffective (Nivola 1986). US companies who were losing market share at an alarming rate needed answers and the prevailing $\mathrm{OM}$ curriculum had none to offer except more refined and elegant quantitative analysis.

In industry, operations managers started to pay attention to how Japanese companies were being managed as explained to them by Johnson and Ouchi (1974), Suginori et al. (1977), Ashburn (1977), and Pascale (1978). By the early 1980s, Japanese production management was beginning to be broadly understood by the industrial organizations in the western world. This was aided greatly by the establishment of Japanese transplant factories in the US and additional publications by Ohno and Kumagai (1981), Shingo (1981), and Monden (1981). Schonberger (2007) reported on the early efforts by industry to create greater understanding of the superiority of the Japanese methods. The Greeley division of Hewlett Packard produced a 29-minute video ${ }^{2}$, "Stockless Production", illustrating the differences among large batch, small batch, and one-piece-flow production. The Repetitive Manufacturing Group meetings included visits to the Kawasaki Motorcycle Plant in Lincoln, Nebraska where the Toyota Production System (TPS) had been cloned and fully implemented. These efforts brought to the attention of operations managers the Japanese system of production and its three interdependent components - employee involvement (quality circles), attention to quality (total quality control), and production-on-demand (Just-In-Time (JIT) or Kanban inventory management).

\subsection{Strategic Scientific Management}

Stalk (1988) brought the Japanese system, specifically JIT, to the boardroom (Schonberger 2007). By the time Stalk's article landed on the desks of top executives, they were already primed by articles which appeared much earlier - the "Missing Link" and "Focused Factory" by Skinner $(1969,1974)$ and the book by Hayes and Wheelwright (1984). These sources argued that manufacturing should be geared towards achieving an organization's strategic objective. That is, optimization of its activities must be determined by what the target market wants and has to go beyond reducing cost and increasing productivity. Another related prescription offered to management was what to do in order to achieve this strategic orientation. Stalk (1988) provided the tools and techniques to management. In short, scientific management ideas from long ago returned to industry. Old ideas were being presented again as prescriptions for industry but this time, in a more concrete, applied fashion with Toyota's approach as the showcase. By 1990, the ascendancy of the TPS, now called lean production (Krafcik, 1988), was complete after Womack et al. (1990) published the results of the exhaustive and rigorous survey of the vehicle assembly plants throughout the world. The main implication of this study was that lean production was superior to mass production in many respects and can be

${ }^{2}$ See https://www.youtube.com/watch?v=yZDRB_z51MQ for part 1 with links to parts 2 and 3 
implemented outside of Japanese culture as evidenced by its effective application in the transplanted assembly plants already operating in North America and the United Kingdom.

These developments were followed by successful attempts by other automobile companies outside Japan, such as Porsche A.G., to implement lean methods, along with prescriptions on how to make the transformation from mass to lean production. The lean approach has also found its way into the service sector, especially healthcare. A number of these cases are documented in Womack and Jones (1996a). These body of empirical research on how companies transformed themselves into lean enterprises showed that, among other things, the change must be viewed as a strategic system of systems - with functional areas as nodes which are integrated with one another. For example, a shift in consumer preferences require adjustments in the marketing mix requiring changes in product development and factory operations, which can then lead to changes in the supply chain and so on until a different strategic value chain emerges (Womack and Jones 1996b)

Furthermore, within each node are subsystems that are also interdependent. For the production function to support the new value chain, a change in inventory management may require an adjustment in the supply chain which can impact new product development and human resource management and so on.

\subsection{Current Coverage of OM in Textbooks}

There are many introductory OM textbooks available for adoption which are published by a variety of reputable publishers involved in the field of higher education. Several of these OM textbooks are in double digit editions such as Heizer et al. (2020), Jacobs and Chase (2021), Russell and Taylor (2019), and Stevenson (2021). These and other OM textbooks typically contain on average 18 chapters and some with several topics in the appendix. The chapters are associated with several OM topics such as forecasting, product design, location, layout, quality, inventory, scheduling, lean operations, aggregate planning, and project management where these topics can in fact, be a full semester if not a yearlong course. Thus, the OM instructor needs to select the appropriate number of chapters for coverage during a 15-week long semester.

In addition, there have been other pedagogical ways of delivering the OM course content over the past few decades. These approaches have included the integration of OM and/or MS-Excel based software packages (Betton et al. 1988) as well as teaching the OM course in a variety of different online learning environment such as hybrid classes to $100 \%$ online classes using learning management systems, multimedia tools, and assessment approaches (Chaudhry et al. 2013, Clouse and Evans 2011, Diaz et al. 2011, Ro et al. 2010). No matter which teaching approach is selected to deliver the OM course content, the selection process related to the content can vary from instructor to instructor at various institutions within the business programs. Hence, the coverage can be relatively varied and the experiences of the students upon graduation are quite diverse.

\subsection{The Academic Disconnect}


While the dynamic strategic nature of operations management was being recognized in industry, the academic world was slow to react. This was despite additional warnings that $\mathrm{OM}$ as a function is now geared towards implementation of complex parallel solutions (Wood and Britney 1988/1989), requiring a more strategic view (Adler 1989; Bahl 1989; Bergman and Flores 1991). OM is no longer a discipline which can be taught in a silo but has to be presented as integrated with other functional areas all geared towards achieving an organization's strategic goal (Gunawardene 1991; Skinner 2007). OM should be taught in the same manner that it is practiced in successful organizations - with less emphasis on the quantitative tools and more realism (Adler 1989). One explanation for the slow response may be found in how faculties gained acceptance in the scientific communities (Skinner 2007) - by behaving as a purely academic discipline, like chemistry or geology, and not as a professional school, like medicine or law (Bennis and O'Toole 2005).

Towards the end of the 1990s, Goffin (1998) reported on the wide diversity in the content of undergraduate OM courses - legacy programs focused on quantitative tools and techniques while others evolved towards focusing on services and including newer topics like globalization. Legacy programs, however, still dominated. OM topics continue to be presented as simplified versions of reality which can be solved by tools which generate localized optimal solutions focused on lowering cost and increasing productivity without regard to other strategic considerations. In contrast, $\mathrm{OM}$ in practice is more complex and this lack of realism in the classroom led to the poor image of the course (Adler 1989). Students not majoring in $\mathrm{OM}$ did not see a need for the subject realizing that they are not likely to use it in practice. It may have reminded them of Algebra back in high school difficult and "useless" because they never got an explanation of how the concepts are related to business related issues in organizations which are actually very useful in practice. OM began to be regarded as a course only for quantitative people.

In response, undergraduate and less established graduate business programs of the liberal arts colleges stopped requiring POM as a core course. Those who continued to offer the OM course did so only as an upper-level elective. Many do not offer the course at all. Thus, when the OM course is not a required core course, programs produce graduates with incomplete knowledge.

This lack of breadth is of particular issue in liberal arts institutions trying to pursue depth as well as breadth in their business curriculum. In our review of the members of the Council of Public Liberal Arts Colleges (COPLAC) and the top 50 liberal arts institutions as ranked by US News and World Report ${ }^{3}, 29$ out of 79 institutions offer business degrees. Among those who did, only 14 required POM as a required core course for all concentrations or majors in business. Thus, at a time when most business managers have said that they would prefer someone from a liberal arts background to become their leaders (Logan and Curry 2015; Appelbaum 2016), most liberal arts institutions graduate business students with insufficient preparation as related to the $\mathrm{OM}$ aspect of organizations.

\section{Bringing Back OM into the Business Curriculum}

${ }^{3 h t t p s: / / w w w . u s n e w s . c o m / b e s t-c o l l e g e s / r a n k i n g s / n a t i o n a l-l i b e r a l-a r t s-c o l l e g e s ~}$ 
There have been attempts to establish more realism and consistency in teaching OM. These efforts have been going on since the late 1960s and 70s. More recent efforts call for a realistic approach that must be founded on solid theoretical foundations. Spearman and Hopp (1998) noted that OM teaching not based on quantitative techniques are too heavy on prescription especially in lot sizing, job-shop scheduling, MRP/ERP, and lean principles. They called for grounding these prescriptions on descriptive models for a stronger theoretical foundation that can be applied to any changing nature of OM. In their view, good descriptive models based on what they termed "factory physics" lead to better prescriptive models. Lovejoy (1998) also called for the necessity of crafting a theory of OM. This can be a broad synthesis of theories from other fields where their interrelationships are expressed in a manner uniquely suited to OM practice. The theory can be built on existing theories in optimization, mathematical programming, queuing, organizations, and so on. The underlying premise here is that a solid theoretical foundation can lead to a better understanding of how OM should be managed. There is no singular way to run operations - it will depend on the current strategic conditions.

Efforts to present an integrated strategic view of OM in the classroom recognizes that this is how OM is practiced by successful organizations (Davies 1996). Several institutions have published their experiences as reported by Pal and Busing (2008). These institutions report on better outcomes by their students in terms of learning and retention of what they learn ${ }^{4}$. Badurdeen et al. (2010) reports on the effectiveness of the use of simulation and games when it comes to teaching lean manufacturing.

Despite the reports on innovations in OM teaching and research, these new approaches have not been able to displace the quantitative Modern Operations Management as the primary approach (Skinner 2007; Sprague 2007). The wide diversity in OM teaching as well as the disjointed presentation of topics persist. In order to address this, Hayes et al. (2007) sought input from a broad range of OM academics and practitioners to create a Collective Causal Map of the subject. They identified 7 factors which impact performance and how they are linked to each other. These are Strategy Focus and Agility, Metrics and Tools, Supply Chain Management, Systems Management, Process Improvement, Quality and HR Management, and Capacity and Demand Management. These linkages are evidence of how these OM factors are interdependent.

These innovations in OM teaching indicate that students find the subject to be relevant when it is presented as an integral part of an overall corporate strategy. This makes it interesting for them. To help them learn the concepts more effectively such that they are able to retain what they absorbed, the topics must be presented as a reflection of what is being done in the field. The topics must also be presented not as individual silos but as a collection of interdependent areas.

In the next sections, this paper makes suggestions on how these can be operationalized.

\section{Presenting OM and its Relation to other Functional Areas}

\footnotetext{
${ }^{4}$ The institutions are University of Idaho, Clemson University, Cal State - Chico, Babson College and James Madison University (Pal and Busing 2008).
} 
The main goal of the approach we are proposing as a guide for teaching is to make OM interesting for business students regardless of their major or concentration. This can happen only if students find a need for the course. Whatever their area of interest may be, they will appreciate having an understanding of OM if they can see how it is interdependent with their own chosen field of study. How operations are managed will have an impact on how other functions need to perform. Consider the case of Hyundai Motors' operations in North America (Magnaye 2013). In this case, the company in 2004 changed its source of competitive advantage from low cost to differentiation based on quality (more appealing design, high initial and long-term dependability) fuel efficiency and improved dealer network. To illustrate the effect of this change in strategy on all other functional areas of the company, we used the Value Chain Model (Porter 1985). The new strategy required a change in technology development from mass production processes (adopted from Mitsubishi, Chrysler and British manufacturers) to the TPS. To be able to implement the change faster, a greenfield factory was established in Alabama with a much smaller capacity and away from the direct influence of its massive plant in South Korea. A new supply chain had to be developed in the US along lean thinking principles. Human resource management had to be modified to address legal and social realities in the US, especially gender and racial diversity. The rest of the results are summarized in Table 1. What this case showed was that a change in strategy led to a new approach to operations which then impacted policies and practices in other areas of the company. Profits were impacted by how well the company was able to synchronize the changes in all areas of the value chain.

When presented in this manner at the very start of the semester, this approach provides the students with an opportunity to recognize that each component of the value chain mirrors the courses that they have taken or will be taking as part of their business curriculum. In addition, the ripple effects of the change in operations (a new smaller lean facility in Alabama) bring home the message that their courses are also interdependent. Students realize that concepts learned from other classes during previous semesters (such as economies of scale, management of workforce diversity, hierarchy of human needs, the 4Ps of marketing, and so on) dovetail with operations management. For example, a product strategy (from Marketing) that is based on low cost advantage aimed at a broad competitive scope will require a repetitive process strategy with low fixed and variable costs having high flexibility to produce models aimed at various market segments. This market strategy calls for a lean production system. However, when the competitive scope is narrow and requires only one or two models, an automated repetitive process is more appropriate. Understanding such nuances leads to engagement picking up during the rest of the semester.

\section{An Integrated Model of OM}

As the semester progresses, it is now necessary to emphasize that each component of operations management is not a silo or distinct topic which can be forgotten, especially after the course assessment. We must continue relating each new topic to the ones which have been completed. For example, in the Product Design module, Design for Sustainability (DFS) calls for the product to be easy to assemble so that at 


\begin{tabular}{|c|c|c|}
\hline & BEFORE 2006 & AFTER 2006 \\
\hline Firm Infrastructure & $\begin{array}{l}\text { Concentrated in S. Korea } \\
\text { Low Cost Strategy } \\
\text { Basic Product }\end{array}$ & $\begin{array}{l}\text { New Subsidiary In US } \\
\text { Differentiation Strategy } \\
\text { Basic Product }\end{array}$ \\
\hline $\begin{array}{l}\text { Technology } \\
\text { Development }\end{array}$ & $\begin{array}{l}\text { Borrow Product Technology } \\
\text { Borrow Process Technology (Mass } \\
\text { Production/Batch and Queue } \\
\text { System) From Mitsubishi, UK }\end{array}$ & $\begin{array}{l}\text { In-House Product Technology } \\
\text { Borrow Process Technology from } \\
\text { Toyota (Lean Production System) }\end{array}$ \\
\hline Operations & $\begin{array}{l}\text { One Big Vertically Integrated } \\
\text { Factory in S. Korea } \\
-1.7 \text { Million Cars Per Year } \\
\text { - High Parts Inventories } \\
\text { - Very Poor Quality } \\
\text { - Very High Production Costs } \\
\end{array}$ & $\begin{array}{l}\text { Second Factory in Alabama } \\
\text { - 200K Cars Per Year } \\
\text { - Low Parts Inventory (JIT) } \\
\text { - Much Improved Quality } \\
\text { - Reduced Costs } \\
\end{array}$ \\
\hline $\begin{array}{l}\text { Human Resource } \\
\text { Management }\end{array}$ & $\begin{array}{l}\text { South Korean Workforce } \\
\text { - Unionized } \\
\text { - Specialized Skills } \\
\text { - Extensive Supervision } \\
\text { - Centralized Decision Making } \\
\text { - Male-Dominated }\end{array}$ & $\begin{array}{l}\text { American Workforce in the US } \\
\text { - Non-Union } \\
\text { - Multi-Skilled, Self-Directed } \\
\text { - Minimal Supervision } \\
\text { - Decentralized Decision Making } \\
\text { - Diversity }\end{array}$ \\
\hline $\begin{array}{l}\text { Procurement } \\
\text { (Supply Chain) }\end{array}$ & $\begin{array}{l}\text { In-House Suppliers (Vertically } \\
\text { Integrated) }\end{array}$ & $\begin{array}{l}\text { Outside Suppliers of Toyota, } \\
\text { Honda, Ford, Other Lean Producers } \\
\text {-Close Partnerships } \\
\text {-Close Proximity }\end{array}$ \\
\hline $\begin{array}{l}\text { Inbound Logistics } \\
\text { (Parts to } \\
\text { Operations) }\end{array}$ & $\begin{array}{l}\text { Short Travel on Forklifts, Trucks, } \\
\text { Conveyors } \\
\text { Delivery in Large Batches } \\
\text { Extensive Quality Checks }\end{array}$ & $\begin{array}{l}\text { Slightly Longer Travel } \\
\text { Delivered JIT } \\
\text { Reduced Quality Checks }\end{array}$ \\
\hline $\begin{array}{l}\text { Outbound Logistics } \\
\text { (Cars to } \\
\text { Dealerships) }\end{array}$ & $\begin{array}{l}\text { Cargo Ships from S. Korea To US } \\
\text { (Large Batches) } \\
\text { Trains } \\
\text { Trucks } \\
\end{array}$ & $\begin{array}{l}\text { Trains } \\
\text { Trucks }\end{array}$ \\
\hline Marketing & $\begin{array}{l}\text { PRODUCT - Basic, Poor Initial } \\
\text { Quality, Poor Long-Term } \\
\text { Dependability } \\
\text { PLACE - "Cheap" Dealerships, } \\
\text { Unprofessional Salespeople } \\
\text { PRICE - Cheapest } \\
\text { PROMOTION - Longest } \\
\text { Warranty, Rebates All Year }\end{array}$ & $\begin{array}{l}\text { PRODUCT - Basic, High Initial } \\
\text { Quality, Excellent Long-Term } \\
\text { Reliability } \\
\text { PLACE - High-End Appearance, } \\
\text { Professional Staff } \\
\text { PRICE - Match Toyota, Honda, } \\
\text { Ford } \\
\text { PROMOTION - Longest Warranty, } \\
\text { Rebates Only at Year-End, "Made } \\
\text { In The USA", Awards Won } \\
\end{array}$ \\
\hline After-Sales-Service & $\begin{array}{l}\text { Plenty of Repairs Under Warranty } \\
\text { Delayed Parts Deliveries for } \\
\text { Repairs ad Maintenance } \\
\end{array}$ & $\begin{array}{l}\text { Much Less Repairs } \\
\text { Greater Availability of Parts for } \\
\text { Repairs And Regular Maintenance } \\
\end{array}$ \\
\hline Margins or Profits & NEGLIGIBLE & COMPETITIVE \\
\hline
\end{tabular}

(Source: Magnaye 2013)

the end of its life, it will also be easy to disassemble, thereby encouraging more reuse and/or recycling. DFS also impacts Design for Manufacturing and Assembly 
(DFM/A) in order to make the product easy to assemble, the architecture must be simple, and the number of parts must be kept to the minimum. These factors directly impact Management of Quality which requires a certain type of workforce development, a short collaborative supply chain, and so on.

We offer as an example, the model depicted in Figure 1. We present lean operations management from the bottom of the diagram beginning with workforce development, product design/project management, and supply chain strategy. These serve as our foundations for building the model up until we are able to integrate ${ }^{5}$ every element into lean operations management. These are explained in greater detail by Magnaye (2017).

As a roadmap for the course, this provides the message that the topics covered earlier in the semester lead to topics that follow so a solid understanding of the former is necessary throughout the class. We have found that this approach helps to sustain the interest of the students and raise engagement throughout the semester.

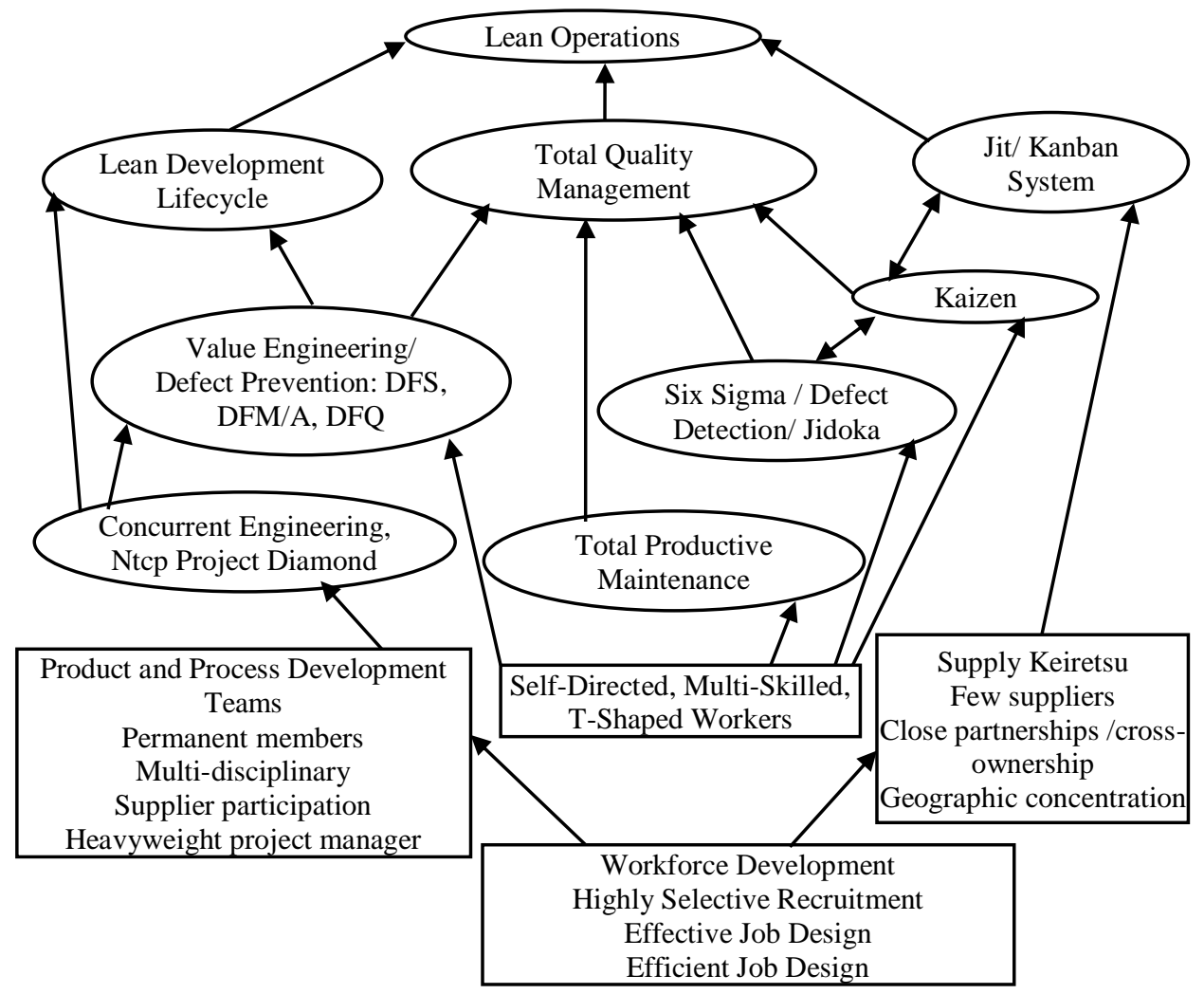

Figure 1 An Integrated Model of Operations Management

\section{Application}

${ }_{5}^{5}$ The diagram shows only the principal integration links. There are secondary links which also exist, such as those within each node. 
After graduation from a doctoral program in Engineering Management from an Institute of Technology, one of the authors was assigned to teach three sections of $\mathrm{OM}$ as a required core course in a liberal arts institution. The classes were small -30 students per section - and the initial plan was to teach the course in a traditional manner, with a heavy orientation on tools and techniques. The classes were not going well and after three weeks, it was clear that a change in pedagogy was required for the classes to be a success. The students wanted:

- To understand how OM is relevant when none of them had any intention to work in the field,

- To see how OM is actually practiced so that they may recognize it where they work, and

- How the tools and techniques are applicable - which situations, under what conditions.

Since the students appear to be instinctively engaged in their learning, the professor asked them for ideas on how to improve the course. One of the most widely made suggestions was to present $\mathrm{OM}$ as part of the whole or the entire organizational enterprise using a framework they were already familiar with from previous courses - Michael Porter's Value Chain (Porter 1985). From this discussion, the Hyundai case (and additional cases) was developed and used to "restart" the course in the $4^{\text {th }}$ week of the semester. It also changed the delivery of the material - from a lecture-heavy methodology to a more participant-centered discussion approach. That old cliché was true - students already know more than what they realize, especially because many of them work significant hours during the semester. During these discussions, the students began to point out that certain OM concepts can be derived from other courses they have already taken, especially Microeconomics, Management of Organizational Behavior, and Marketing. Furthermore, they also pointed out that policies implemented in OM, such as those for inventory management and human resource management eventually showed up in Accounting and financial statements. In short, they realized the role that OM plays in an organization - they could now see "the big picture".

Eventually, from this approach to OM teaching, students made more contributions which were incremental in nature. They wanted class participation to be rewarded more in terms of its weight in grading. From their own work experiences, they were able to identify which concepts are no longer widely used (such as batch-and-queue) in favor of newer concepts (such as one-piece-flow). From these inputs, we determined which topics to include and how they were to be presented in an integrated fashion as presented in Figure 1.

\section{Future Research Work}

Additional work on this methodology is warranted by the fact that OM continues to evolve in practice. This paper focused heavily on the lean $\mathrm{OM}$ in manufacturing. However, the mix of sectoral output in most economies have shifted a while ago in a significant fashion such that today, much of production activities are now happening in the service sector. While we argue that much of the ideas depicted in Figure 1 also apply to service operations, this may only be true as far as their generic essence is concerned. For example, service products must be designed just as manufactured products do. However, the differences of the nature of these products may render the 
current activities used to design goods may be inappropriate or ineffective when it comes to services which are very dependent on customer-provider interactions. We need more field studies to come up with a service-centric model of OM. Our hope is that the current imbalance in OM research and teaching as reported by Slack et al. (2004), where OM research in services account for only $10 \%$ of all research in the field, can be corrected.

Furthermore, we propose the ideas put forth in section 3 especially those by Spearman and Hopp (1998) and Lovejoy (1998) be combined into a model for teaching operations management with more realism. We suggest that OM be taught as a collection of descriptive models based on field observations (as in the time of Agricola and Scientific Management - see section 2.1), explained as reflections of theories which have been developed in the fields of strategy, organizational behavior, cognitive science, mathematical programming, optimization, and so on. From such descriptive models and theoretical foundations, prescriptive models can then be formulated as a guide for practitioners in the field.

Finally, we also hope to report on the results of incorporating new and emerging technologies into operations management. Block chain technology, data science, next generation communications, small lot transportation systems, and supply chain disruptions are some of the topics that will be inserted into the teaching of the Operations Management course.

\section{Conclusions}

This paper attempted to explain how OM became so uninteresting for liberal arts students by looking at how the discipline evolved - how practice diverged from teaching. We also looked at what teaching innovations have been reported to be successful. Based on these, we proposed a systemic approach to presenting OM concepts in the classroom which can increase interest in the subject as well as assist students retain the knowledge. This approach was grounded on concepts that students already had been exposed to in their prior business courses. Finally, we made recommendations on where the discipline should be headed given the state of industry where service operations now employ most of our graduates while only a few ends up with jobs in manufacturing.

\section{References}

1. Adler, P.S. (1989), "When knowledge is the critical resource, knowledge is the critical task", IEEE Transactions on Engineering Management, Vol. 36(No. 2), pp. 87-94.

2. Appelbaum, Y. (2016), "Why America's business majors are in desperate need of a liberal arts education", The Atlantic, (June 28, 2016).

3. Ashburn, A. (1977), "Toyota's "famous Ohno system", American Machinist, Vol. 7, pp. 120-123.

4. Bahl, H.C. (1989), "Teaching Production and Operations Management at the MBA level - a survey", Production and Inventory Management Journal, Vol. 30(No. 3), pp. 5-7. 
5. Badurdeen, F., Marksberry, P. Hall, A., and Gregory, B. (2010), "Teaching lean manufacturing with simulations and games: a survey and future directions", Simulation \& Gaming, Vol. 41(No. 4), pp. 465-486.

6. Bennis, W.G., and O'Toole, J. (2005), "How business schools lost their way", Harvard Business Review, Vol. 83(No. 5), pp. 9-104.

7. Bergman, R.L., and Flores, B.E. (1991), "Operations Management curriculum: challenges for the 1990s and beyond", Operations Management Review, Vol.8 (No. 2), pp. 47-55.

8. Betton, J., Chaudhry, S.S., Ross, Jr., W.H., and Xu, L.D. (1988), "Integrating microcomputer software packages into the business curriculum", Education \& Computing, Vol. 4, pp. 91-97.

9. Chaudhry, P.E., Chaudhry, S.S., and Sudler, H. (2013), "Successfully merging technology with knowledge creation: an overview of distance learning techniques", International Journal of Operations and Quantitative Management, Vol. 19(No. 1), pp. 39-57.

10. Clouse, S.F., and Evans, G.E. (2011), "The effect of computer-based multitasking on learning in an undergraduate operations management course", International Journal of Operations and Quantitative Management, Vol. 17(No. 1), pp. 59-83.

11. Davies, H. (1996), "Reflect real life: teach operations through drivers not techniques". In: Proceedings of the Conference on Teaching POM: Visions, Topics and Pedagogies.

12. Diaz, A., Lorenzo, O., and Fernández, M. (2011), "Teaching operations management using alternative delivery means", International Journal of Operations and Quantitative Management, Vol. 17(No. 4), pp. 349-359.

13. Goffin, K. (1998), "Operations Management teaching on European MBA programmes", International Journal of Production Management, Vol. 18(No. 5), pp. 451-454.

14. Gordon, R.A., and Howell, J.E. (1959), "Higher Education for Business". Ford Foundation Study. NY: Columbia University Press.

15. Gunawardene, G. (1991), "Trends in teaching management science in undergraduate business programs", Interfaces, Vol. 21(No. 5), pp. 16-21.

16. Hayes, J.M., Bouzdine-Chammera, T., Goldstein, S.M., Hill, A.V., and Scavarda, A.J. ( 2007), "Applying the collective causal mapping methodology to Operations Management curriculum development", Decision Sciences Journal of Innovative Education, Vol. 5(No. 2), pp. 267-287.

17. Hayes, R., and Wheelwright, S. (1984), Restoring Our Competitive Edge: Competing Through Manufacturing. NY: John Wiley.

18. Heizer, J., Render, B., and Munson, C. (2020), Operations Management: Sustainability and Supply Chain Management, $13^{\text {th }}$ Edition, Pearson Education, Inc.

19. Jacobs, F.R., and Chase, R. (2021), Operations and Supply Chain Management, $16^{\text {th }}$ Edition, McGraw-Hill Education.

20. Johnson, R., and Ouichi, W. (1974), "Made in America (under Japanese Management)", Harvard Business Review, Vol. 52(No. 5), pp. 61-69.

21. Krafcik, J.F. (1988), "Triumph of the lean production system", Sloan Management Review, Vol. 30(No. 1), pp. 41-52. 
22. Liker, J.K., Hoseus, M., and the Center for Quality People and Organizations (2008), Toyota Culture: The Heart and Soul of the Toyota Way, NY: McGraw Hill.

23. Logan, J., and Curry, J. (2015), "A liberal arts education: global trends and challenges", Christian Higher Education, Vol. 14(No. 1/2), pp. 66-79.

24. Lovejoy, W.S. (1998), "Integrated operations: a proposal for operations management teaching and research", Production and Operations Management, Vol. 7(No. 2), pp. 106-124.

25. Magnaye, R. B. (2013), the radical transformation of Hyundai in the USA. (unpublished teaching case)

26. Magnaye, R. B. (2017), an integrated model of operations management. (unpublished teaching note)

27. Monden, S. (1981), "What makes the Toyota production system really tick?" Industrial Engineer, January, pp. 36-46.

28. Nivola, P. S. (1986), "The new protectionism: U.S. trade policy in historical perspective", Political Science Quarterly, Vol. 101(No. 4), pp. 577-600.

29. Ohno, T., and Kumagai, T. (1981), Toyota production system in Abdulhan and Tabucanon (eds.) Decision Models for Industrial Systems Engineers and Managers, Elmsford, NY: Pergamon Press.

30. Pal, R., and Busing, M.E. (2008), "Teaching Operations Management in an integrated format: student perception and faculty experience", International Journal of Production Economics, Vol. 115 (No. 2), pp. 594-610.

31. Pascale, R.T. (1978), "Zen and the art of management", Harvard Business Review, Vol. 56(No. 2), pp. 153-162.

32. Pierson, F.C. (1959), the Education of American Businessmen. Carnegie Study, NY: McGraw Hill.

33. Porter, M.E. (1985), Competitive Advantage: Creating and Sustaining Superior Performance, NY: The Free Press.

34. Raizadeh, F.M.E., and Ettkin, L.P. (1989), "Production and Operations Management in academia: some causes for concern", Production and Inventory Management Journal, Vol. 30(No. 2), pp. 37-40.

35. Ro, Y.K., Guo, Y.M., Rossin, D., and Klein, B.D. (2010), "Flow and learning outcomes in an online operations management course", International Journal of Operations and Quantitative Management, Vol. 16(No. 2), pp. 191-216.

36. Russell, R.S., and Taylor, B.W. (2019), Operations and Supply Chain Management, $10^{\text {th }}$ Edition, John Wiley \& Sons.

37. Schonberger, R.J. (2007), "Japanese production management: an evolution with mixed success”. Journal of Operations Management, Vol. 25(No. 2), pp. 403-419.

38. Shingo, S. (1981), Study of "Toyota" Production System from Industrial Engineering Viewpoint, Tokyo: Japan Management Association.

39. Skinner, W. (1969), "Manufacturing- missing link in corporate strategy", Harvard Business Review, 47(3), pp. 136-145.

40. Skinner, W. (1974), "The focused factory", Harvard Business Review, Vol. 52(No. 1), pp. 113-121.

41. Skinner, W. (2007), "Manufacturing Strategy: the story of its evolution", Journal of Operations Management, Vol. 25(No. 2), pp. 328-335. 
42. Spearman, M.L., and Hopp, W.J. (1998), "Teaching Operations Management from a science of manufacturing", Production and Operations Management, Vol. 7(No. 2), pp. 132-145.

43. Sprague, L.G. (2007), "Evolution of the field of Operations Management", Journal of Operations Management, Vol. 25(No. 2), pp. 219-238.

44. Stalk, Jr. G. (1988), "Time- the next source of competitive advantage", Harvard Business Review, Vol. 66(No. 4), pp. 41-51.

45. Stevenson, W.J., (2021), Operations Management, $14^{\text {th }}$ Edition, McGraw-Hill Education.

46. Suginoori, Y., Kusunoki, K., Cho, F., and Uchikawa, S. (1977), "Toyota production system and Kanban system: materialization of Just-in-time and respect-for-human", International Journal of Production Research, Vol. 15(No. 6), pp. 553-564.

47. Thompson, K. (ed) (2003), Early Sociology of Management \& Organizations Volume 1: Scientific Management, London: Routledge.

48. Voss, C.A. (2007), "Learning from the first Operations Management textbook", Journal of Operations Management, Vol. 25(No. 2), pp. 239-247.

49. Wilson, J.M. (2018), "Deconstructing the re-invention of Operations Management", Journal of Management History, Vol. 24(No. 2), pp. 128-155.

50. Womack, J., Jones, D., and Roos, D. (1990), The Machine that Changed the World. Lean Thinking, NY: Free Press.

51. Womack, J., and Jones, D. (1996a), Lean Thinking, NY: Free Press.

52. Womack, J., and Jones, D. (1996b), "Beyond Toyota: how to root out waste and pursue perfection", Harvard Business Review, Vol. 74(5), pp. 4-16.

53. Wood, A.R., and Britney, R.R. (1988/1989), "Production and operations management: research and teaching opportunities in the 1990s", Operations Management Review, Vol. 7(No. 2), pp. 33-42.

\section{About Our Authors}

Romulo Babor Magnaye teaches at the Anisfield School of Business of Ramapo College and is a Visiting Scholar at the University of North Texas. He is a Robert Crooks Stanley Fellow and a British Council Fellow. He has taught at Stevens Institute of Technology, Penn State, Skidmore College, and Rensselaer Polytechnic Institute. Before joining the academe, he worked in the Philippines for Philex Mining Corporation, the National Development Company, and in the Office of the Secretary of Natural Resources. He has a B.S. (Mining Engineering) and MBA from the University of the Philippines, a Postgraduate Diploma from Camborne School of Mines, and a Ph.D. from Stevens Institute of Technology. He is a registered Professional Mining Engineer.

Sohail S. Chaudhry is a Professor in the Department of Management and Operations at Villanova School of Business. He received his B.Sc. in Mechanical Engineering from Mosul University, Iraq, and his M.S. and Ph.D. in Industrial Engineering and Operations Research from Columbia University. His research and teaching interests are in the areas of Operations and Supply Chain Management and Information Systems. He serves as a member on the Editorial Advisory Boards of 
several international journals and as an Associate Editor of Enterprise Information Systems and Journal of Industrial Integration and Management. Previously, he has taught at Columbia University, Loyola University Chicago, Mosul University, and University of Wisconsin at La Crosse.

Brian Sauser is a Professor at the University of North Texas in the G. Brint Ryan College of Business. He serves as the Director of the Complex Logistics Systems Laboratory, Program Coordinator of the Logistics Systems Ph.D. Program, and Degree Architect of the BS in Industrial Distribution. He is a NASA Faculty Fellow, UNT Faculty Leadership Fellow, Professional Development Institute Business Fellow, IEEE Senior Member, and Associate Editor of the IEEE Systems Journal. He holds a B.S. from Texas A\&M University, M.S. from Rutgers, The State University of New Jersey, and Ph.D. from Stevens Institute of Technology.

Nikhil Varma is an academician and industry advisor. He has over 12 years of industry experience working as a developer, architect, product and program manager, and management consultant. He is a trained software engineer with a bachelor's and master's in computer engineering. He also did his MBA from HEC. Montreal, Canada. His Ph.D. was focused on service design strategies using machine learning and was completed in 2013 from HEC Montreal. He is currently an assistant professor in the Anisfield School of Business at Ramapo College of New Jersey. He teaches Operations, Data Visualization, Business Analytics, and Sustainability. 